\title{
Seasonal patterns in round goby (Neogobius melanostromus) catch rates, catch composition, and dietary quality
}

Brauer, Meike; Behrens, Jane; Christoffersen, Mads; Hyldig, Grethe; Jacobsen, Charlotte; Björnsdottir, Katla Hrund; van Deurs, Mikael

\section{Published in:}

Fisheries Research

Link to article, DOI:

10.1016/j.fishres.2019.105412

Publication date:

2020

Document Version

Peer reviewed version

Link back to DTU Orbit

Citation (APA):

Brauer, M., Behrens, J., Christoffersen, M., Hyldig, G., Jacobsen, C., Björnsdottir, K. H., \& van Deurs, M. (2020). Seasonal patterns in round goby (Neogobius melanostromus) catch rates, catch composition, and dietary quality. Fisheries Research, 222, [105412]. https://doi.org/10.1016/j.fishres.2019.105412

\section{General rights}

Copyright and moral rights for the publications made accessible in the public portal are retained by the authors and/or other copyright owners and it is a condition of accessing publications that users recognise and abide by the legal requirements associated with these rights.

- Users may download and print one copy of any publication from the public portal for the purpose of private study or research.

- You may not further distribute the material or use it for any profit-making activity or commercial gain

- You may freely distribute the URL identifying the publication in the public portal 
1 Target journal: Fisheries Research

2

3 Title: Seasonal patterns in round goby (Neogobius melanostromus) catch rates, catch

4 composition, and dietary quality.

5

6 Authors: Meike Brauer ${ }^{1}$, Jane W Behrens ${ }^{1}$, Mads Christoffersen ${ }^{1}$, Grethe Hyldig ${ }^{2}$, Charlotte

7 Jacobsen $^{2}$, Katla H. Björnsdottir ${ }^{1}$, Mikael van Deurs ${ }^{1}$

8

9 Author affiliation:

$10{ }^{1}$ Technical University of Denmark, Institute for Aquatic Resources, Lyngby, Denmark

$11{ }^{2}$ Technical University of Denmark, National Food Institute, Lyngby, Denmark

13 Corresponding author: Mikael van Deurs (mvd@aqua.dtu.dk)

15 Abstract:

16 The round goby (Neogobius melanostomus; Pallas, 1814) is one of the most widespread

17 invasive fish species. It originates from the Black Sea and the Sea of Azov, but has un-

18 intentionally been introduced to fresh and brackish water bodies on both sides of the Atlantic.

19 Small-scale fishermen catch large amounts of the invasive round goby in their nets as the

20 species continues to spread and populate new areas of the Baltic Sea. In the present study we

21 were concerned with the possibilities for a "use and reduce" solution to the round goby

22 invasion. However, in order to capture the interest of restaurants, supermarkets, and 


\section{Introduction}

Invasive non-indigenous species can put pressure on the native fauna through predation or

37 species not only act as environmental pressures, but also local societies and economies may suffer.

39 Some examples of this could be touristic disadvantages and declines in fishery and aquaculture

40 opportunities, leading to less production and therefore less employment (Bax et al., 2003).

41 Consequently, much effort has over the years been put into the development of new ways of

42 controlling or reducing invasive species and prevent them from spreading further (Ojaveer et al., 43 2015).

44 In the Baltic Sea alone, around 100-118 species have been identified as non-indigenous 45 (HELCOM, 2012). Among those species, one of the most successful invaders is the round goby 
(Neogobius melanostomus; Pallas, 1814) originating from the Black Sea and the Sea of Azov. The round goby has spread into various fresh and brackish water bodies on both sides of the Atlantic. It has invaded the Laurentian Great Lakes in North America and connecting rivers and channels (Charlebois et al., 2001; Corkum et al., 2004; Young et al., 2009). In the 1990s, the species was observed for the first time in the Baltic Sea, more specifically in the Gulf of Gdansk (Sapota and Skóra, 2005), where it established a dense population and later spread into adjacent areas (Azour et al., 2015; Kotta et al., 2015; Sapota \& Skóra, 2005). It was suggestively introduced via ballast water to the Gulf of Gdansk (Kotta et al., 2015). Nowadays, it is common for small-scale fishermen to find round goby in their nets and traps as by-catch over large parts of the Baltic Sea (Ojaveer, 2006). The spread and the numbers of round goby are increasing, posing a risk to the local environment and biodiversity. It competes for space and food with indigenous fish (Balshine et al., 2005; Karlson et al., 2007), and previous research has shown that round gobies can negatively impact other species of fish in part by eating their eggs and young (Chotkowski and Marsden, 1999; French and Jude, 2001; Steinhart et al., 2004). Moreover, local fishermen experience a loss of income, since fishing their target species has become impossible in some areas due to large amounts of round goby filling up fishing gears.

Among the endeavors to fight invasive species, we find examples of "use and reduce" solutions, which stems from the notion, that if the economical incentive for harvesting an invasive species is high enough, population numbers (of the invasive species) will be reduced over time, and hopefully this will result in a positive feedback on the native fauna, that was pressured by the arrival of the invasive species in the first place (Karp \& Wyatt, 2017; Reise, 1998; Wessel, 2004).

One of the most famous examples from northern Europe are the red king crab (Paralithodes camtschaticus). In the 1960s, the red king crab was first introduced to the Bering Sea and the Murmansk area (Falk-Petersen et al., 2011; Hjelset, 2014; Orlov and Ivanov, 1978). From here it spread further and the first crabs in Norwegian waters were caught in Varanger in 1977. In 2002, a 
commercial fishery was established in Norway, based on a quota system to benefit those

72 fishermen who suffered economically from the invasive species due to by-catch and destroyed

73 gear. The fishery is today of high value (app. 9 million Euro in 2003) and local fishermen have

74 become more or less economically dependent on this species (Wessel, 2004).

75 Seen in light of the king crab example and given that the round goby is already commercially

76 harvested in some parts of the Black Sea region (Jude et al., 1992; Kornis et al., 2012) and sold as

77 fresh fish or as canned products (Zarev et al., 2013), a "use and reduce solution" for the round

78 goby appears to be within reach. However, in order to capture the interest of restaurants,

79 supermarkets, and distributers, more knowledge about the seasonality in availability and

80 nutritional and sensory quality is needed.

81 Knowledge about the expected seasonal fluctuations in size, condition (i.e. weight relative to

82 length) and catch rates provide a useful foundation for planning of fishing activities and

83 infrastructure. Knowing the chemical composition of the fish meat (i.e. the fillet) may play an

84 essential role in the marketing process of new fish products. Proteins make up most of fish meat

85 and the content range from 10 to $25 \%$ in lean fish species (Huss, 1995; Nunes et al., 2006). On

86 average, more fatty species contain relative less protein, but are often rich in healthy lipids. Fish

87 lipids are, for example, an excellent source of the long-chain omega 3 unsaturated fatty acids.

88 These are essential for the human body and leads to a reduced risk of cardiovascular diseases and

89 improved mental health, immune system and infant brain development (Song et al., 2016;

90 Wysoczanski et al., 2016; Nichols, et al., 2014). Last, but not least, also the meat firmness (i.e.

91 texture), which is part of the sensory quality, is very important for the consumer acceptance and

92 for the processing, especially when the fish is filleted (Rasmussen et al., 201; Ingerslev et al.,

93 2012). 
In the present study we collected round goby bycatch data from three invaded sites in Southern Denmark (Western Baltic Sea) in 2017. With this data we (1) assembled the most (to this date) detailed description of the catch rates and catch composition (from size and gender distribution to the chemical composition of the fillets) of round gobies caught in a commercial fishery, and (2) tested for seasonal patterns in these data (i.e. differences between months).

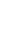

\section{Materials and Methods}

Fishing for round goby I from April 2017 to November 2017 and involved three small scale fishers using fyke nets to target eels. A recent tagging study has shown that during this period the round goby favors shallow, coastal water and thus is caught in the small-scale fisheries operating near the coast (Christoffersen et al., 2019). As reported by the fishermen, the fyke nets were always fishing for 72-94 $\mathrm{h}$ and were of similar types and mesh sizes (30 $\mathrm{mm}$ fyke nets). The three fishers were located in Guldborgsund, Kalvehave, and Karrebæksminde, respectively (Fig. 1) and were asked to maintain a logbook, recording the amount of by-caught round goby and the number of fyke nets used, which allowed us to use monthly catch per unit effort (CPUE) (i.e. kg/fyke net) as a measure of relative abundance. To reduce the time of handling, the size of catches was approximated by establishing the weight of a $20 \mathrm{~L}$ bucket filled with round goby after which all landings were measured in numbers of buckets times the weight of a full bucket. The fishers also put aside two sets of samples during the fishing season. The first set of samples was collected on a monthly basis and consisted of $>200$ individuals from a random fyke net catch. These samples were placed in a $-18 \mathrm{C}$ freezer and were later used to determine size, condition factor, and gender distributions. Spread out over the year a total of 3707 fish were measured to the nearest $\mathrm{mm}$ (1047, 1516, and 1144 from Guldborgsund, Kalvehave, and Karrebæksminde, respectively). The fish were then sorted into centimeter intervals and 10 fish from each centimeter interval (or all if less 
than 10) were saved for further analyses, which involved weighing the fish to the nearest 0.1

grams and determining sex by examination of the urogenital papilla (Charlebois et al., 1997).

Fulton's condition factor $(\mathrm{K})$ was calculated as $\left(\mathrm{W} / \mathrm{L}^{3}\right) \times 10^{5}$, where $\mathrm{W}$ is the weight of the fish (in grams) and L is the standard length in mm (Ricker, 1975).

The second set of samples were collected in April, June, August and November and consisted of 20 fresh fish fillet from each month (80 in total) from relatively large gobies only $(>12 \mathrm{~cm})$. Fillets were put on ice and transported to the laboratory on the day of capture and analyzed the next day with respect to fat content, protein content, fatty acid composition, and texture.

The lipid and protein content were determined in altogether 76 fillets (4 fillets were lost during preparation for lab. analyses). The analysis required c. $30 \mathrm{~g}$ of tissue per sample and another $30 \mathrm{~g}$ were needed for the subsequent fatty acid FAME analysis (see description below). It was therefore necessary to pool fillets in groups of two or three. In total 37 pooled samples were analyzed $(11,6$, 14, and 6 from April, June, August, and November, respectively). The lipid content was determined by the Bligh \& Dyer method (Bligh and Dyer, 1959) using a reduced amount of solvent. Lipid content of the material was extracted by utilizing a homogenous mix of chloroform $\left(\mathrm{CHCL}_{3}\right)$, methanol $\left(\mathrm{CH}_{3} \mathrm{OH}\right)$ and ion-exchanged water, with the ratio of 2:2:1.8. Samples were centrifuged at $2800 \mathrm{rpm}$ for 10 minutes, filtered and dried (here the dry matter of the fillet could also be determined). Final lipid content was determined gravimetrically. The protein content was determined chemically by analyzing the nitrogen content applying the Dumas method for quantitative determination of nitrogen in different matrices (Elementar, Mt. Laurel, NJ, USA). Samples where combusted at $900^{\circ} \mathrm{C}$ under the influence of oxygen with a flow of $180 \mathrm{ml}$ per minute. The pressure applied was $1450 \mathrm{mbar} \pm 50 \mathrm{mbar}$ and for calibration, $250 \mathrm{mg}$ aspartic acid was used as standard. Conversion of the estimated total nitrogen content to the crude protein was done using a conversion factor of 6.25 . 
The contribution of different fatty acid methyl esters to the total lipid pool in fillets from Guldborgsund was quantified and described using gas liquid chromatography. All fatty acids in the triglycerides, phospholipids and free fatty acids were converted into fatty acid methyl esters. Fatty acid profile was determined based on the American Oil Chemist's Society (AOCS) official method Ce 1b-89 and Ce 1i-07 with some modifications. Approximately $2 \mathrm{~g}$ of Bligh \& Dyer extract was weighted in methylation glass tube and evaporated under a stream of nitrogen until dryness. A mixture containing $100 \mu \mathrm{L}$ of internal standard solution (C23:0), $200 \mu \mathrm{L}$ of heptane with BHT and $100 \mu \mathrm{L}$ of toluene was added to the dry extract. Samples were methylated in a microwave oven (Microwave 3000 SOLV, Anton Paar, Ashland, VA, USA) for $5 \mathrm{~min}$. at $100{ }^{\circ} \mathrm{C}$ and power of 500 watts. After methylation, heptane with BHT (0.7 $\mathrm{mL})$ and saturated salt water $(1 \mathrm{~mL})$ were added. The upper phase (heptane) was transferred into HPLC vials and analysed by gas chromatography (HP-5890 A, Agilent Technologies, Santa Clara, CA, USA). Fatty acid methyl esters were separated by the GC column Agilent DB wax 127-7012 (10 $\mu \mathrm{m}$ x $100 \mu \mathrm{m}$ x $0.1 \mu \mathrm{m})$ (Agilent technologies, Santa Clara, CA, USA). Standard mix of fatty acids methyl esters (Sigma, St. Louis, MO, USA) was used for fatty acid identification. Fatty acids were quantified as area $\%$ of total fatty acids. Analyses were carried out in duplicate. The different types of fatty acids were grouped into six categories commonly reported in nutritional studies: MUFA (monounsaturated fatty acids), DHA (Docosahexaen acid, 22:6 n-3), EPA (Icosapentaen acid, 20:5 n-3), PUFA (polyunsaturated fatty acids), PA (palmitic acid, C16:0), SFA (saturated fatty acids), n-3 (omega-3 fatty acid), and n-6 (omega-6 fatty acid). Note that although we refer to these as fatty acid groups, some, such as DHA, EPA, and PA constitute single fatty acids. Note also that $n-3$ and $n-6$ is contained also within PUFA, just as PA is contained within SFA. 
The firmness (i.e. texture) of the meat was measured with a TPA on all 80 fish fillets, using compression test on raw fillet, two measuring point on each fillet (see figure 2). The force, [N], at a single compression to $40 \%$ of initial sample thickness was recorded (TA.XT2® Texture Analyser). The compression was performed in longitudinal configuration with a $10 \mathrm{~mm}$ probe with rounded edges and the probe speed was $1 \mathrm{~mm} / \mathrm{sec}$ (for further details see Rasmussen et al. 2011).

For CPUE, length, and condition factor the null hypothesis, stating that there were no differences between the different sample months and study areas, was tested using two-way ANOVA statistics. For lipid content, protein content, and firmness, only differences between months were investigated (using one-way ANOVA), since the proximate chemical composition and firmness was only determined in samples from Guldborgsund.

\section{Results}

Significant differences in CPUE was found between months (ANOVA: $\mathrm{F}_{7,124}=34.1, \mathrm{p}<0.001$ ) and study areas (ANOVA: $\mathrm{F}_{2,124}=3.64, \mathrm{p}=0.029$ ). May was the month with the highest CPUE at all three location. Mean CPUE ranged between 7 and $10 \mathrm{~kg}$ per net in May and the overall highest CPUE was observed for Kalvehave. Except for Guldborgsund, where CPUE in April was nearly as high as in May, all other months produced CPUEs that was $<50 \%$ of May. In Guldborgsund, there was a second peak in CPUE in September, although much smaller than in May. Whereas, in Kalvehave and Karrebæksminde, CPUEs dropped rapidly after May and fated more or less out from July and onwards (Fig. 3 and Table 1). 
The majority of fish were males in all locations (average: $74.6 \%$ ). There was also a common seasonal pattern, characterized by a peak in the percentage of males during mid-summer and a low in fall (Fig. 4).

Average length was $12.0 \mathrm{~cm}$. Significant differences in length were found between months (ANOVA: $F_{7,4668}=140.0, p<0.001$ ) and study areas (ANOVA: $\left.F_{2,4668}=981.2, p<0.001\right)$. However, a visual inspection of the monthly differences did not reveal any common seasonal patterns (Fig. 5). In Karrebæksminde, the largest fish were found during summer (July and August), whereas, spring yielded the largest mean lengths in Kalvehave. In Guldborgsund, mean length fluctuated from month to month, with no apparent seasonal pattern. However, all differences were minute and were presumably only tested significant because of the relatively large sample sizes. All length distributions appeared unimodal, making it impossible to distinguish between cohorts based on length alone (Fig. 6).

Condition factor $(\mathrm{K})$ did not differ significantly between months (ANOVA: $\mathrm{F}_{7,1059}=32.9$, $\mathrm{p}<$ $0.001)$ and study areas (ANOVA: $\left.F_{2,1059}=31.4, p<0.001\right)$. A visual inspection of the seasonal dynamics revealed a distinct pattern common for all three areas (most pronounced in Kalvehave and Karrebæksminde) (Fig. 7). In all three areas a peak in K was observed in May, hereafter K decreased gradually from June to August, and from August to November K increased again. Table 1 summarizes average values of CPUE, length, weight, and K.

The assessment of the nutritional profile and meat firmness was based on data from Guldborgsund only. Mean oil content differed significantly between months (ANOVA: $F_{3,33}=49.0, p<0.001$ ), gradually increasing from spring towards fall. Lipid content peaked at $1 \%$ in November (opposed to $0.64 \%$ in April) (Fig. 8). The protein content increased significantly from $17.3 \%$ in April to $18.8 \%$ in August (ANOVA: $\mathrm{F}_{3,33}=21.75, \mathrm{p}<0.001$ ), where after a small drop occurred between 
212

213

214

215

217

218

219

220

221

222

223

224

227

.

August and November (Fig. 8). Firmness of fillets was highest in November (2.70 N \pm 0.58$)$ and lowest in June $(0.83 \mathrm{~N} \pm 0.32)\left(\mathrm{ANOVA}: \mathrm{F}_{3,76}=61.7, \mathrm{p}<0.001\right)$ (Fig. 9).

DHA was the most common of the fatty acid methyl esters (averaging $17.2 \%$ of the total pool of fatty acids across months) (Table 2) and the only fatty acid to show a notable seasonal pattern, displaying a significant drop around August (Fig. 10). The overall mean proportion of PUFA (across months) was $50.6 \%$, whereas, MUFA only constituted $14.6 \%$ on average. The omega-3 type of fatty acids (n-3) constituted $38 \%$ of the total pool of fatty acids.

\section{Discussion}

Local fishermen and ecosystems in the Baltic Sea are pressured by the sheer number of round gobies invading coastal areas including estuaries and shallow bays. In the present study, fishermen from three locations in southern Denmark (western Baltic) reported all by-catches of round goby in 2017 and collected monthly samples for detailed analysis of seasonal catch composition, catch efficiency and quality of the fish. All to assess the potential for a cost-efficient, use and reduce commercial fishery for a species, which is currently unwanted bycatch in many coastal fisheries.

Round goby catch per unit effort (CPUE) was highest in May and lowest in July/August, suggesting that a fishery for this species would be most efficient during late spring. The observed CPUE ranged between less than $1 \mathrm{~kg} / \mathrm{net}$ up to a maximum of $10 \mathrm{~kg} / \mathrm{net}$ (or 1 tons of round goby landed during a single fishing session, which equals 100 fyke nets left at sea for 3-4 days). As these data are based on bycatch of round goby in a fishery targeting flatfish and European eel, higher CPUE may indeed be achieved in a fishery targeting round goby. In support of the potential for high catch rates of round goby, an ongoing data-collection program, between researchers and 
fishermen, have shown that round goby is more frequently encountered in catches than some of the most common indigenous species, such as European flounder (Platichthys flesus, L.) and eelpout (Zoarces viviparous, L.) (Støttrup et al., 2018). This agrees well with densities of c. two round goby $\mathrm{m}^{-2}$, which was recorded during snorkel surveys in the same areas (Azour et al., 2015; Christoffersen et al., 2019). In Muuga Bay (Gulf of Finland), the fish accounts for more than $80 \%$ of the catches in gillnets of mesh size 36-44 mm (ICES, 2017), and along the quite limited Lithuanian coastal area (100 km wide) over 200 tons of gobies were caught in 2016 and 2017 (NRC 2016, 2017). Still, the largest round goby landings in the Baltic Sea are currently taking place in Latvian coastal waters, where fishery logbook data evidence a sharp increase in catches from less than 1 ton in 2011 to over 500 tons in 2016 (Kornilovs, 2017).

When using passive fishing gear, such as fyke nets, catch rates are highly dependent on fish behavior and activity (Diana et al., 2006), and the present pronounced difference in CPUE between months (with the same overall trend for all three areas) may reflect behavioral changes of the round goby, rather than actual difference in number of fish in the areas. For example, round goby feed intensively during the pre-spawning spring period, inferring high activity and mobility, and then start aggregating in June, where males prepare the nests and females swim around and choose nests (Meunier et al., 2009). In July and August, the fish are rather stationary and immobile as the males guard the nests and the females spawn (Meunier et al., 2009; Skabeikis and Lesutiene, 2015).

All three locations in the present study were dominated by male round gobies. The areas were invaded between 2009 and 2011 (Azour et al., 2015), and the populations of round gobies here may thus be considered well established. Compared to more recently established populations, older populations are often characterized by having male bias (Brandner et al., 2013; Grul'a et al., 2012; Gutowsky and Fox, 2012), which confers with the present findings. Males however are also considered to be more active than females and hence more prone to be caught by passive gear, 
which may be one additional factor explaining the male bias in the present catches (Marentette et al., 2011; Skabeikis and Lesutiene, 2015).

Not only the amount caught in the fishery, but also the size composition and quality of the catch is of utmost importance, as this largely determines its utilization and hence prize. Round goby is a relatively small fish and in the present three study areas the length averaged $12 \mathrm{~cm}$. Round goby may occasionally attain an average size of up to $19 \mathrm{~cm}$ in some parts of the Baltic Sea (Melvere et al., 2017). However, a maximum length of $22 \mathrm{~cm}$, as found in the present study, suggested that the growth potential here is similar to most areas in the Baltic Sea, where studies have reported maximum lengths between $18 \mathrm{~cm}$ and $23 \mathrm{~cm}$ (Mierzwicka, 2000; Pliszka, 2002; Skora and Stolarski, 1996; Sokołowska and Fey, 2011); and higher compared to its native range (the PontoCaspian region and the Black Sea), where maximum length range from $18 \mathrm{~cm}$ to $19 \mathrm{~cm}$ (Apostolou et al., 2014; Macun, 2018)

As mentioned above, the breeding season peak in July and August (Skabeikis and Lesutiene, 2015), where round goby consequently display reduced feeding activity (MacInnis and Corkum, 2000; Skabeikis and Lesutiene, 2015). Condition factor often follows feeding and breeding cycles (Rätz and Lloret., 2003; Mozsár et al., 2015). Hence, the observed low condition between June and August is probably related to weight loss resulting from spawning and nest guarding behavior. After the spawning period, feeding resume and the condition increases again prior to winter (Skabeikis and Lesutiene, 2015).

Firmness refers to the physical and sensorial properties of the meat and is used as an indicator of quality in food science (Chen and Rosenthal 2015). The firmness of the round goby fillet, measured in present study, was $0.8-2.7$ N. For comparison, Rasmussen et al. (2011) reported the firmness of farmed trout (Oncorhynchus mykiss) to be between 1.1 and $3.3 \mathrm{~N}$, whereas, herring fillets (Clupea harengus) measured in Nielsen et al. (2005) was considerably firmer 
(2.45 - $5.88 \mathrm{~N}$ compressed to $60 \%$; as opposed to $40 \%$ in the present study). As expected seasonal differences in firmness of round goby followed dynamics in the condition factor and proximate chemical composition (lipids and proteins).

The chemical composition of fish depends on food intake and season (Aidos et al., 2002; Huss 1995; Skabeikis and Lesutiene, 2015). Especially, the lipid content of fish may undergo considerable fluctuations during the course of a year (Aidos et al., 2002; Aro et al., 2000; Gladyshev et al., 2009). Fish gather energy prior to spawning and use that energy during spawning, resulting in a rapid decline in lipids (Love, 1988). As mentioned above, the main spawning period for round goby is July and August, possibly explaining the decrease in lipid content observed in the present study. The observed decline of DHA in August may also be related to spawning, as DHA is used for egg production (Tocher, 2010). The remaining fatty acids and fatty acid groups presented here (EPA, MUFA, n-3, n-6, PA, PUFA, and SFA) remained relatively stable between sample months.

In general, the fish were rather lean (fat content up to 1\%) with a high protein content (17-19\%). Protein content was comparable to that of cod fillets (Gadus morhua) (16-19\%), whereas, the lipid content was slightly higher (0-0.4\% in cod fillets) (Waterman, 2001), but still much lower than reported for more fatty species, such as herring (Clupea harengus), which, can amount up to 1725\% (Jensen et al., 2007; van Deurs et al., 2018). The lipid and protein content found here also resembled that of a previous round goby study, which found mean lipid content of $0.67 \%$ and mean protein content of $16.6 \%$ in April (Melvere et al., 2017).

Compared to Strobel et al. (2012), the proportion of EPA and DHA in cod is much higher than in round goby analyzed in the present study. Strobel et al. (2012) showed mean values of around 51 $\%$ EPA+DHA, compared to c. $30 \%$ in the present study. In comparison, Jensen et al. (2007) found that EPA+DHA varied from 14 to $21.6 \%$ in herring and Strobel et al. (2012) found that rainbow 
3321033.

trout contained $16.6 \%$ EPA+DHA. The proportion of total PUFA $(50.6 \%)$ was at the same level as that found in pollock and Alaska pollock and much higher than that found in herring, tuna and rainbow trout (Strobel et al., 2012). The proportion of palmitic acid in round goby is comparable to that in herring, salmon and rainbow trout. The proportion of SFA in round goby is low (23.2\%) and at the same level as that in herring, pollock, Alaska pollock and rainbow trout, but much lower than that in tuna $(34.8 \%)$ (Strobel et al., 2012).

Overall, these data suggested that round goby has a favorable fatty acid composition and meat quality comparable to other species used for human consumption. Catch rates peaked in spring, whereas meat firmness, lipids and protein peaked in the second half of the year. However, while nearly a doubling in lipid content could be achieved by targeting round goby in fall, opposed to spring, the relative gain in terms of protein, from a targeting round goby in late summer, is minute. Hence, in the cases where lean fish is favored, the high catch rates achieved in spring may be what determines what is the best fishing season. Average size was more or less the same throughout the year, therefore size optimization should be made with gear choice rather than timing the fishery.

\section{Acknowledgement}

We wish to thank recreational fishermen Tonny Rasmussen, John Jensen, and Cextin for catching the fish used in the study. Also, thanks to Farivar Azour for assisting on the project. The present research has been conducted within the project "Sustainable use of the invasive round goby in favour of industry and environment (SORTMUND)", financed by the Green Development and Demonstration Program (GUDP) of the Ministry of Environment and Food; Grant:34009-15- 


\section{References}

335 Aidos, I., van der Padt, A., Luten, J. B., Boom, R. M., 2002. Seasonal, changes in crude and lipid composition of

336 herring fillets, byproducts, and respective produced oils. Journal of Agricultural and Food Chemistry, 50 (16), 4589-

3374599

338 AOCS Official method, Ce 1b-89. Saturated, cis-Monounsaturated, and cis-Polyunsaturated Fatty Acids in Marine

339 and Other Oils Containing Long Chain Polyunsaturated Fatty Acids (PUFAs) by Capillary GLC, Boulder, Illinois.

340 AOCS Official Method Ce 1i-07. Fatty Acid Composition of Marine Oils by GLC, Boulder, Illinois.

341 Apostolou, A., Velkov, B., and Vassilev, M., 2014. Growths, age and size structure of the round goby (Neogobius

342 melanostomus) from its main habitats in Bulgarian waters.

343 Aro, T., Tahvonen, R., Mattila, T., Nurmi, J., Sivoneh, T. \& Kallio, H., 2000. Effects of season and processing on oil

344 content and fatty acids of Baltic herring (Clupea harengus membras). J Agric. Food Chem.48 (12), $6085-6093$.

345 Azour, F., Deurs, M. v., Behrens, J., Carl, H., Hüssy, K., Greisen, K., Ebert, R. \& Møller, P. R., 2015. Invasion rate

346 and population characteristics of the invasive round goby Neogobius melanostomus: effects of density and invasion

347 history. Aquatic Biology 24, 41-52.

348 Balshine, S., Verma, A., Chant, V. \& Theysmeyer, T., 2005. Competitive interactions between round gobies and

349 logperch. Journal of Great Lakes Research, 31 (1), 68-77. Bax, N., Williamson, A., Aguero, M., Gonzalez, E. \&

350 Geeves, W., 2003. Marine invasive alien species: a threat to global biodiversity. Marine Policy, 27 (4), 313 -323.

351 Bligh, E. G. and Dyer, W. J., 1959. A rapid method of total lipid extraction and purification. Canadian Journal of 352 Biochemistry and Physiology, 37 (8), 911-917.

353 Brandner, J., Cerwenka, A. F., Schliewen, U. K. \& Geist, J., 2013. Bigger Is Better: Characteristics of Round Gobies

354 Forming an Invasion Front in the Danube River. PLOS ONE, 8 (9), e73036.

355 Charlebois, P. M., Corkum, L. D., Jude, D. J. \& Knight, C., 2001. The Round Goby (Neogobius melanostomus)

356 Invasion: Current Research and Future Needs. Journal of Great Lakes Research 27 (3), 263-266. 
357

358

359

360

361

362

363

364

365

366

367

368

369

370

371

372

373

374

375

376

377

378

379

380

381

382

Charlebois, P. M., Marsden, J. E., Geottel, R. G., Wolfe, R. K., Jude, D. J., \& Rudnicka, S., 1997. The round goby, Neogobius melanostomus (Pallas), a review of European and North American literature. Illinois-Indiana Sea Grant Program and Illinois Natural History Survey. INHS Special Publication No. 20.

Chen, J. and Rosenthal, A., 2015. 1 - Food texture and structure. Modifying Food Texture. Woodhead Publishing Series in Food Science, Technology and Nutrition, 3-24.

Chotkowski, M.A., Marsden, J.E., 1999. Round goby and mottled sculpin predation on lake trout eggs and fry: field predictions from laboratory experiments. Journal of Great Lakes Research. 25, 26-35.

Christoffersen, M., Svendsen, J., Behrens, J., Jepsen, N., Deurs, M., 2019. Using acoustic telemetry and snorkel surveys to study diel activity and seasonal migration of round goby (Neogobius melanostomus) in an estuary of the Western Baltic Sea. Fish Manag Ecol. 26, 172- 182.

Corkum, L. D., Sapota, M. R. \& Skora, K. E., 2004. The Round Goby, Neogobius melanostomus, a Fish Invader on both sides of the Atlantic Ocean. Biol. Invasions 6 (2), 173-181.

Diana, C.M., Jonas, J., Claramung, R., Firtsimons, J., Marsden, J.E., 2006. A Comparison of Methods for Sampling round Goby in Rocky Littoral Areas. North American Journal of Fisheries Management 26(3), 514-522.

Falk-Petersen, J., Renaud, P. \& Anisimova, N., 2011. Establishment and ecosystem effects of the alien invasive red king crab (Paralithodes camtschaticus) in the Barents Sea-a review. ICES Journal of Marine Science 68 (3), $479-488$.

French, J.R.P.I.I.I., Jude, D.J., 2001. Diets and diet overlap of nonindigenous gobies and small benthic native fishes co-inhabiting the St. Clair River, Michigan. Journal of Great Lakes Research. 27, 300-311.

Gladyshev, M. I., Sushchik, N. N., Makhutova, O. N. \& Kalachova, G. S., 2009. Content of essential polyunsaturated fatty acids in three canned fish species. Int J Food Sci Nutr. 60 (3), 224-230.

Grul'a, D., Balážová, M., Copp, G. \& Kováč, V., 2012. Age and growth of invasive round goby Neogobius melanostomus from middle Danube. Cent.Eur.J. Biol.7 (3), 448-459.

Gutowsky, L.F.G. \& Fox, M.G., 2012. Intra-population variability of life-history traits and growth during range expansion of the invasive round goby, Neogobius melanostomus. Fisheries Management and Ecology 19 (1), 78-88.

HELCOM, 2012. HELCOM List of non-indigenous and cryptogenic species in the Baltic Sea. Available at: 
012).xlsx (accessed: 25.02.2018).

Hjelset, A. M., 2014. Fishery-induced changes in Norwegian red king crab (Paralithodes camtschaticus) reproductive potential. ICES Journal of Marine Science, 71 (2), 365-373.

Ingerslev, H.-C., Hyldig, G., Przybylska, D., Frosch, S. and Nielsen, M.E., 2012. Previous Bacterial Infection Affects Textural Quality Parameters of Heat-treated Fillets From Rainbow Trout (Oncorhynchus Mykiss). Journal of Food Quality 35, 228-237.

Huss, H. H., 1995. Quality and quality changes in fresh fish. FAO Fisheries Technical Paper. Rome: FAO.

ICES, 2017. Report of the ICES Working Group on Introduction and Transfers of Marine Organisms (WGITMO). ICES WGITMO Report 2017 ICES CM 2017 / SSGEPI:09.

Jensen, K.N., Jacobsen, C., Nielsen, H.H., 2007. Fatty acid composition of herring (Clupea harengus) - Influence of time and place of catch on n-3 PUFA content. Journal of Science in Food and Agriculture 87, 710-718.

Jude, D. J., Reider, R. H. \& Smith, G. R., 1992. Establishment of Gobiidae in the Great Lakes Basin. Canadian Journal of Fisheries and Aquatic Sciences 49 (2), 416-421.

Karlson, A. M., Almqvist, G., Skóra, K. E. \& Appelberg, M., 2007. Indications of competition between nonindigenous round goby and native flounder in the Baltic Sea. ICES Journal of Marine Science 64 (3), 479-486.

Karp, P. \& Wyatt, S., 2017. When life gives you lionfish: Innovation in fighting invasive species in the Caribbean. Global Environment Facility Global Environment Facility. Available at: https://www.thegef.org/blog/when-life-givesyou-lionfish-innovation-fighting-invasive-species-caribbean (accessed: 16.05.2018).

Kornilovs, G., 2017. The state of fish stocks and catch control in the Baltic Sea in 2016-2017 (in Latvian).

Kornis, M. S., Mercado-Silva, N. \& Vander Zanden, M. J., 2012. Twenty years of invasion: a review of round goby Neogobius melanostomus biology, spread and ecological implications. J. Fish Biol., 80 (2), 235-285.

Kotta, J., Nurkse, K., Puntila, R. \& Ojaveer, H. 2015. Shipping and natural environmental conditions determine the distribution of the invasive non-indigenous round goby Neogobius melanostomus in a regional sea. Estuarine Coastal and Shelf Science 169, 15-24. 
Love, R. M., 1988. Maturation and spawning. In Love, M. R. (ed.) Food fishes: Their intrinsic variation and practical implications. London, UK: Farrand Press, 43-88.

MacInnis, A. J. and Corkum, L. D., 2000. Fecundity and Reproductive Season of the Round Goby Neogobius melanostomus in the Upper Detroit River. Transactions of the American Fisheries Society 129 (1), 136-144.

Macun, S., 2018. The Growth and Reproduction Characteristics of the Population of Neogobius melanostomus, which is an Invasive Species at European and North American Water Bodies, in Lake Karaboğaz (Black Sea, Tukey) that is Their Native Habitat. Hacettepe Journal of Biology and Chemistry 45 (4), 617-628.

Marentette, J. R., Wang, G., Tong, S., Sopinka, N. M., Taves, M. D., Koops, M. A. \& Balshine, S., 2011. Laboratory and field evidence of sex-biased movement in the invasive round goby. Beha.Ecol. Sociobiol. 65 (12), 2239-2249.

Melvere, M., Ivanovs, K., Pubule, J. and Blumberga, D., 2017. Use of round goby (Neogobius melanostomus) processing waste in bioeconomy. Energy Procedia 128, 484-490. Meunier, B., Yavno, S., Ahmed, S. and Corkum, L. D., 2009. First documentation of spawning and nest guarding in the laboratory by the invasive fish, the round goby (Neogobius melanostomus). Journal of Great Lakes Research 35 (4), 608-612.

Mierzwicka, A., 2000. Morphology of otoliths, age and growth rate of round goby (Neogobius melanostomus) from the Gulf of Gdansk: MSc Thesis, University of Gdansk, Gdynia, Poland (in Polish).

Mozsár, A., Boros, G., Sály, P., Antal, L. and Nag, S.A., 2015. Relationship between Fulton’s condition factor and proximate body composition in three freshwater fish species. J. Appl. Ichthyol. 31, 315-320.

Nielsen, D., Hyldig, G., Nielsen, J., \& Nielsen, H. H., 2005. Liquid holding capacity and instrumental and sensory texture properties of herring (Clupea harengus L.) related to biological and chemical parameters. Journal of texture studies, 36(2), 119-138.

NRC (Nature Research Centre), 2016. Evaluation of smelt and round goby stock in the Baltic Sea and recommendations for sustainable exploitation. Research project report (in Lithuanian). Nature Research Centre, Vilnius, 96 p.NRC (Nature Research Centre) 2017. Assessment of fish stocks in the Curonian Lagoon and recommendations for sustainable exploitation and minimisation of by-catch of protected species. Research project report (in Lithuanian). Nature Research Centre, 123.

Nichols, P. D., McManus, A., Krail, K., Sinclair, A. J., \& Miller, M., 2014. Recent advances in omega-3: Health benefits, sources, products and bioavailability. Nutrients 6, 3727-3733. 
435

436

437

438

439

440

441

442

443

444

445

446

447

448

449

450

451

452

Nunes, M. L., Bandarra, N., Oliveira, L., Batista, I. \& Calhau, M. A., 2006. Composition and nutritional value of fishery products consumed in Portugal: WAGENINGEN ACAD PUBL.

Ojaveer, H., 2006. The round goby Neogobius melanostomus is colonising the NE Baltic Sea. Aquatic Invasions 1 , $44-$

Ojaveer, H., Galil, B. S., Lehtiniemi, M., Christoffersen, M., Clink, S., Florin, A.-B., Gruszka, P., Puntila, R. \& Behrens, J., 2015. Twenty five years of invasion: management of the round goby Neogobius melanostomus in the Baltic Sea. Management of Biological Invasions, 6 (4), 329-339.

Olenin, S., Gollasch, S., Lehtiniemi, M., Sapota, M. \& Zaiko, A., 2017. Biological invasions. In SnoeijsLeijonmalm. Biological Oceanography of the Baltic Sea, 193-232.

Orlov, Y. I. and Ivanov, B. G., 1978. On the introduction of the Kamchatka King crab Paralithodes camtschatica (Decapoda: Anomura: Lithodidae) into the Barents Sea. Mar. Biol. 48, 373.

Pliszka, J., 2002. Morphology of otoliths, age and growth rate of round goby (Neogobius melanostomus) from the Vistula Lagoon: MSc Thesis, University of Gdansk, Gdynia, Poland (in Polish).

Rasmussen, R.S., Heinrich, M.T., Hyldig, G., Jacobsen, C. and Jokumsen, A., 2011. Moderate exercise of rainbow trout induces only minor differences in fatty acid profile, texture, white muscle fibres and proximate chemical composition of fillets. Aquaculture 314, 159-164..

Reise, K., 1998. Pacific oysters invade mussel beds in the European Wadden Sea. Pazifische Austern bevölkern Miesmuschelbänke im europäischen Wattenmeer. Senckenbergiana maritima, 28 (4-6), 167-175.

Ricker WE 1975 Computation and interpretation of biological statistics of fish populations. Bull. Fish Res. Board Can. $191 ; 1-382$.

Rätz, HJ., and Lloret, J., 2003. Variation in fish condition between Atlantic cod (Gadus morhua) stocks, the effect on their productivity and management implications. Fisheries Research 60 (2-3), $369-380$.

Sapota, M. R. \& Skóra, K. E., 2005. Spread of alien (non-indigenous) fish species Neogobius melanostomus in the Gulf of Gdansk (south Baltic). Biol. Invasions 7 (2), 157-164.

Skabeikis, A. and Lesutiene, J., 2015. Feeding activity and diet composition of round goby (Neogobius melanostomus, Pallas 1814) in the coastal waters of SE Baltic Sea. Oceanological and Hydrobiological Studies 44 (4), 508-519. 
Skora, K. and Stolarski, J. (1996). Neogobius melanostomus (Pallas) a new immigrant species in the Baltic Sea.

463

464

465

466

467

468

469

470

471

472

473

474

475

476

477

478

479

480

481

482

483 484 Fisheries and Aquatic Research, SIFAR, 2001: Ministry of Technology.

485

Proceed. of the 2nd Intern. Estuar. Symp.1,101 -108. 2009. Acting separately or synergistically? Prog. Lipid Res. 62, 41-54. during experimental catch-and-release angling. Trans Am. Fish. Soc. 133, 21-131. Lipids Health Dis. 11, 144-144. Hamilton Harbour. Journal of Great Lakes Research 36, 115-122. lipids. Ecol. Evol. 6, 4076-4087. fishery. University of Tromsø.

Sokołowska, E. and Fey, D., 2011. Age and growth of the round goby Neogobius melanostomus in the Gulf of

Gdańsk several years after invasion. Is the Baltic Sea a new Promised Land? Journal of fish biology 78 (7), 1993-

Song, C., Shieh, C., Wu, Y., Kalueff, A., Gaikwad, S., \& Su, K. 2016. The role of omega-3 polyunsaturated fatty acids eicosapentaenoic and docosahexaenoic acids in the treatment of major depression and Alzheimer's disease:

Steinhart, G.B., Marschall, E.A., Stein, R.A., 2004. Round goby predation on smallmouth bass offspring in nests

Støttrup, J.G., Kokkalis, A., Brown, E.J., Olsen, J., Andersen, S.K., Pedersen, E.M., 2018. Harvesting geo-spatial data on coastal fish assemblages through coordinated citizen science. Fisheries Research 208, 86-96.

Strobel, C., Jahreis, G. \& Kuhnt, K. 2012. Survey of n-3 and n-6 polyunsaturated fatty acids in fish and fish products.

Tocher, D.R., 2010. Fatty acid requirements in ontogeny of marine and freshwater fish. Aquac. Res. 41, 717-732.

Young, J.A.M, Marentette, J.R., Gross, C., McDonald, J.I, Verma, A., Marsh-Rollo, S.E., Macdonald, P.D.M., Earn, D.J.D., Balshine, S., 2009. Demography and substrate affinity of the round goby (Neogobius melanostomus) in

van Deurs, M., Persson, A., Lindegren, M., Jacobsen, C., Neuenfeldt, S., Jørgensen, C., \& Nilsson, P. A. (2016). Marine ecosystem connectivity mediated by migrant-resident interactions and the concomitant cross-system flux of

Waterman, J. J., 2001. The cod. Torry Advisory Note. FAO in partnership with Support unit for International

Wessel, K., 2004. The profitability and management of the Norwegian Red King Crab (Paralithodes Camtschaticus) 
487 Wysoczanski, T., Sokoła-Wysoczanska, E., Pekala, J., Lochynski, S., Czyz, K., Bodkowski, R., Herbinger, G.,

488 Patkowska-Sokola, B., \& Librowski, T., 2016. Omega-3 fatty acids and their role in central nervous system - A

489 review. Curr. Med. Chem. 23, 816-831.

490 Zarev, V., Apostolou, A., Velkov, B. \& Vassilev, M., 2013. Bulgarian black sea gobies as important object in the

491 commercial fishing. Bulg. J. Agric. Sci. 19 (2), 233-236.

492

493

494 Table 1. Summary of fisheries data.

\begin{tabular}{|c|c|c|c|c|c|c|c|}
\hline & Sex & Guldborgsund & Kalvehavesund & Karrebæksmindesminde & All Areas & Min & $\operatorname{Max}$ \\
\hline \multirow[t]{3}{*}{ Length $(\mathrm{cm})$} & All & $9.7 \pm 2.2$ & $12.9 \pm 2.0$ & $11.9 \pm 1.8$ & $11.3 \pm 2.5$ & 0.5 & 22.0 \\
\hline & Male & $9.9 \pm 2.3$ & $13.2 \pm 1.9$ & $12.1 \pm 1.7$ & $11.7 \pm 2.5$ & & \\
\hline & Female & $9.5 \pm 2.0$ & $11.5 \pm 1.9$ & $11.2 \pm 1.8$ & $10.2 \pm 2.1$ & & \\
\hline \multirow[t]{3}{*}{ Weight (g) } & All & $23.5 \pm 16.2$ & $29.1 \pm 25.2$ & $29.7 \pm 19.6$ & $32.4 \pm 22.1$ & 1.0 & 176.0 \\
\hline & Male & $25.8 \pm 17.3$ & $42.3 \pm 24.6$ & $32.5 \pm 19.9$ & $34.7 \pm 22.5$ & & \\
\hline & Female & $19.4 \pm 13.2$ & $26.0 \pm 23.1$ & $17.7 \pm 13.4$ & $21.1 \pm 17.2$ & & \\
\hline \multirow[t]{3}{*}{$\mathrm{K}$ - factor } & All & $1.5 \pm 0.2$ & $1.6 \pm 0.2$ & $1.5 \pm 0.2$ & $1.5 \pm 0.2$ & 0.5 & 2.4 \\
\hline & Male & $1.5 \pm 0.2$ & $1.6 \pm 0.2$ & $1.5 \pm 0.2$ & $1.6 \pm 0.2$ & & \\
\hline & Female & $1.5 \pm 0.2$ & $1-6 \pm 0.3$ & $1.4 \pm 0.2$ & $1.5 \pm 0.2$ & & \\
\hline CPUE (kg/net) & & $2.6 \pm 2.3$ & $1.3 \pm 2.3$ & $1.1 \pm 1.5$ & $1.4 \pm 2.1$ & 0.0 & 10.0 \\
\hline
\end{tabular}

495

496

497

498 Table 2. Summary of the relative contribution (\%) of the different fatty acid groups to the overall

499 pool of fatty acids in the fillet.

\begin{tabular}{ccc}
\hline Fatty acid group & Mean \% & Standard deviation \\
\hline EPA & 14.7 & 0.5 \\
DHA & 17.2 & 4.6 \\
PUFA & 50.6 & 6.1 \\
Total n-3 & 38 & 4.3 \\
Total n-6 & 10.7 & 1.3
\end{tabular}




\begin{tabular}{ccc} 
PA & 15.6 & 1 \\
MUFA & 14.6 & 3 \\
SFA & 23.2 & 1.1 \\
\hline
\end{tabular}

502

503

504 Figure 1. Map of survey sites. The study locations are indicated by dots connected to the name of 505 the location.

506

507 Figure 2. The points on the fish fillet, where the texture measurements were conducted.

508

509 Figure 3. Average catch per unit effort (CPUE; kg/net) of round goby calculated by month and

510 location: Guldborgsund (white), Kalvehave (grey), and Karrebæksminde (black).

512 Figure 4. Gender proportions in percentages calculated for each month and study area,

513 respectively. Males (Black) and females (grey).

515 Figure 5. Length distributions presented for each month and study area: (A) Guldborgsund, (B)

516 Kalvehave and (C) Karrebæksminde. Horizontal dashed lines represent the overall mean length

517 across all months and locations. The boxes encapsulate all data points between the $25 \%$ and $75 \%$

518 quantiles and the horizontal black bar represents the median. Error bars represents 5\% and 95\%

519 quantiles. 
521 Figure 6. Length frequency distribution in (A) Guldborgsund, (B) Kalvehave and (C)

522 Karrebæksminde.

523

524 Figure 7. Condition factor presented for each month and study area: (A) Guldborgsund, (B)

525 Kalvehave and (C) Karrebæksminde. Horizontal dashed lines represent the overall mean length

526 across months and locations. The boxes encapsulate all data points between the $25 \%$ and $75 \%$

527 quantiles and the horizontal black bar represents the median. Error bars represents 5\% and 95\%

528 quantiles.

529

530 Figure 8. Dietary quality of round goby fillets from Guldborgsund presented for each month (76

531 fillets). (A) Total lipid content (\% of wet weight), (B) total protein content (\% of wet weight). The

532 boxes encapsulate all data points between the $25 \%$ and $75 \%$ quantiles and the horizontal black bar 533 represents the median. Error bars represents $5 \%$ and $95 \%$ quantiles.

534

535 Figure 9. Firmness (i.e. texture) of the meat measured in number of Newtons (N) it takes to

536 compress the meat to $40 \%$ of initial thickness. The boxes encapsulate all data points between the

$53725 \%$ and $75 \%$ quantiles and the horizontal black bar represents the median. Error bars represents

$5385 \%$ and $95 \%$ quantiles. Horizontal dashed lines represent the overall mean length across all

539 months and locations.

540

541 Figure 10. Fatty acid (fatty acid methyl esters) composition in round goby fillets from

542 Guldborgsund. Fatty acids were grouped into six categories commonly reported in nutritional

543 sciences: MUFA (monounsaturated fatty acids), DHA (Docosahexaen acid), EPA (Icosapentaen 
544 acid), PUFA (polyunsaturated fatty acids), PA (palmitic acid), SFA (saturated fatty acids), n-3

545 (omega-3 fatty acid), and n-6 (omega-6 fatty acid). Columns show the percentage of total fatty 546 acids.

547

548

549

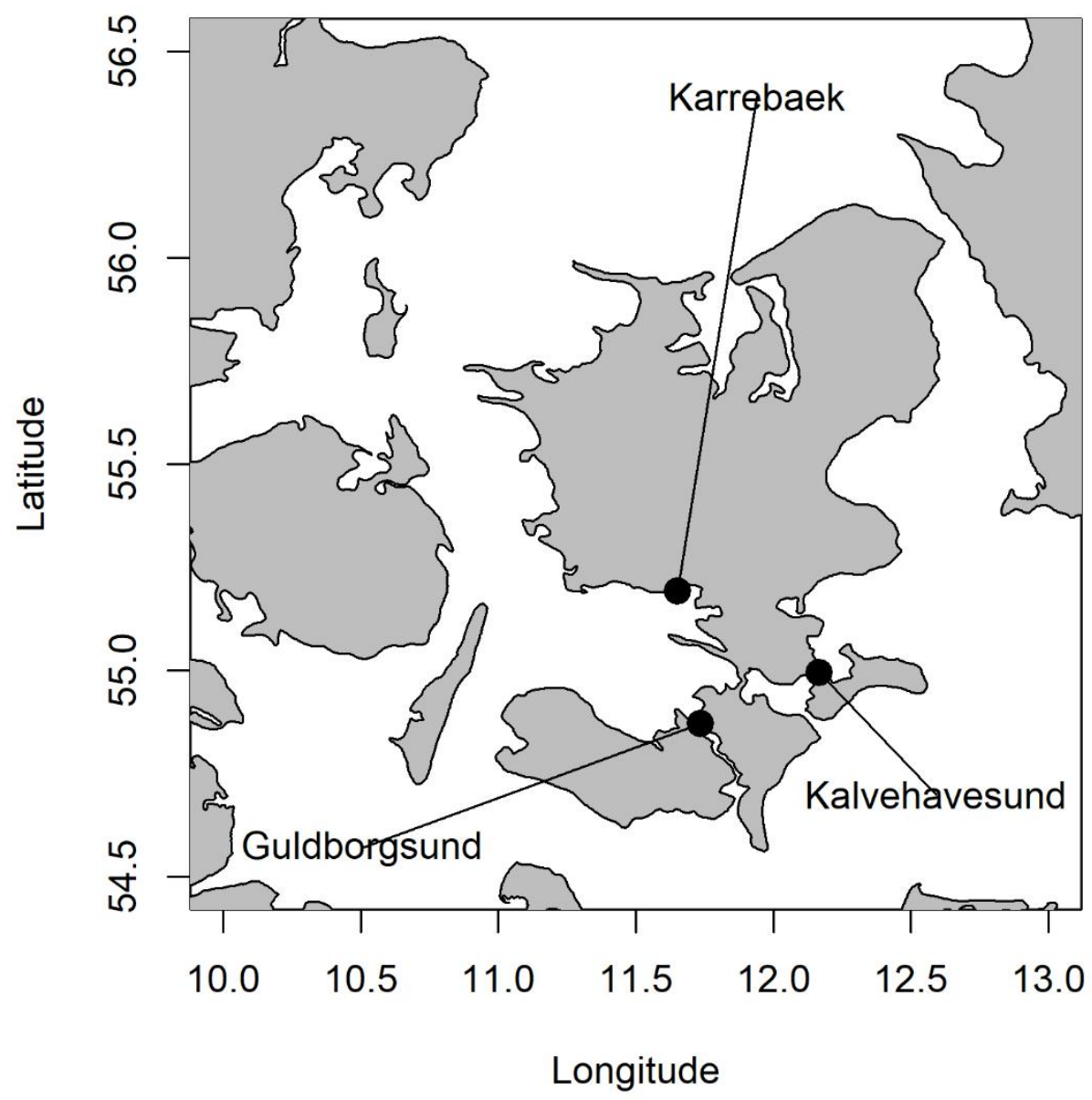

550

551 Fig 1 


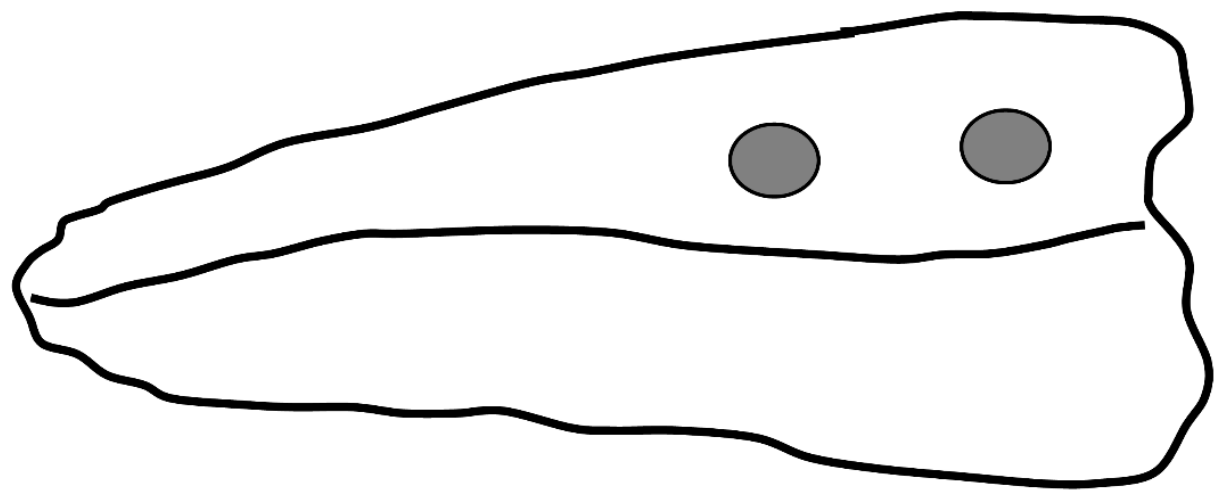

$553 \quad$ Fig 2

554

555

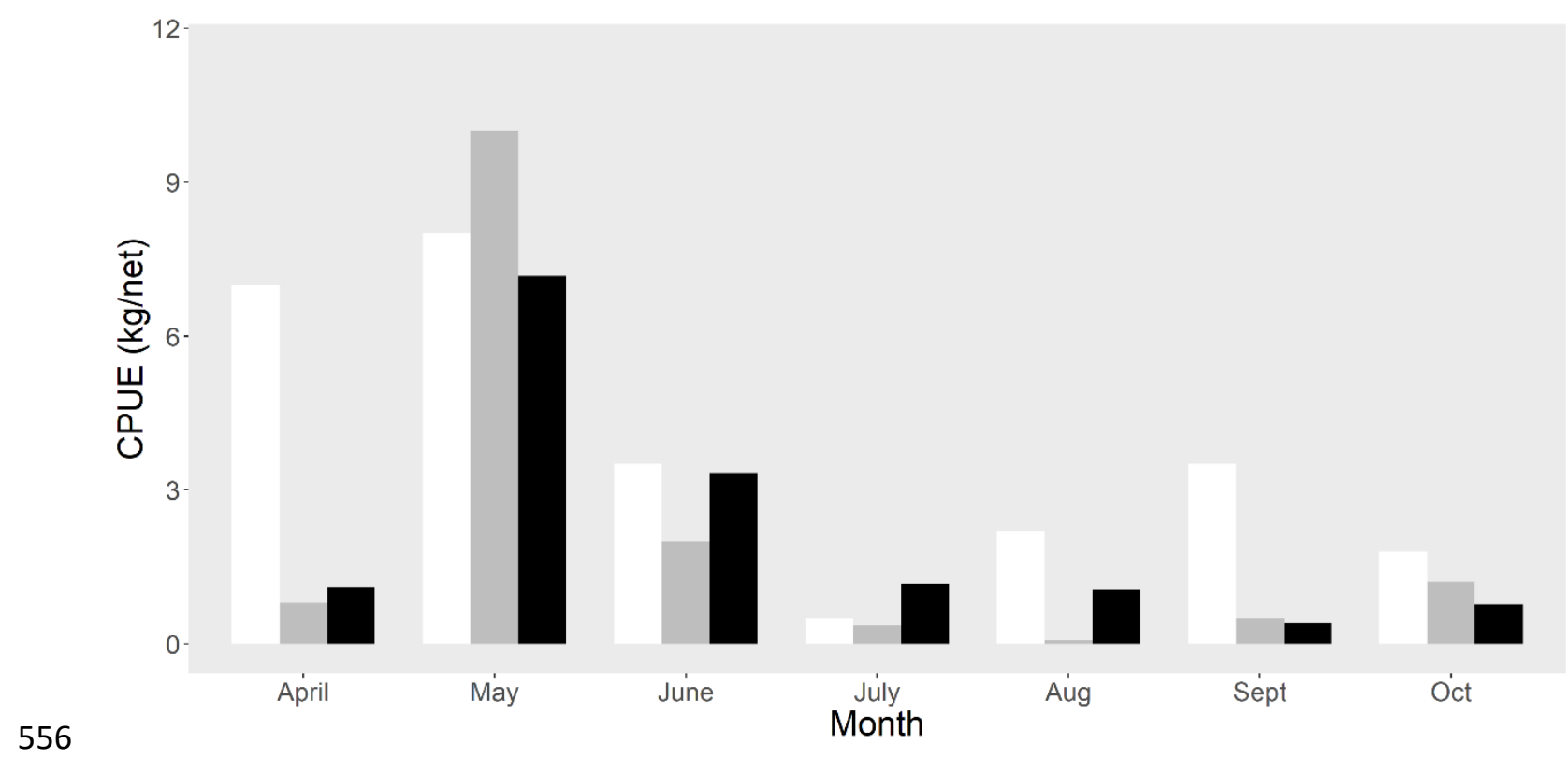


$557 \quad$ Fig 3

558

559

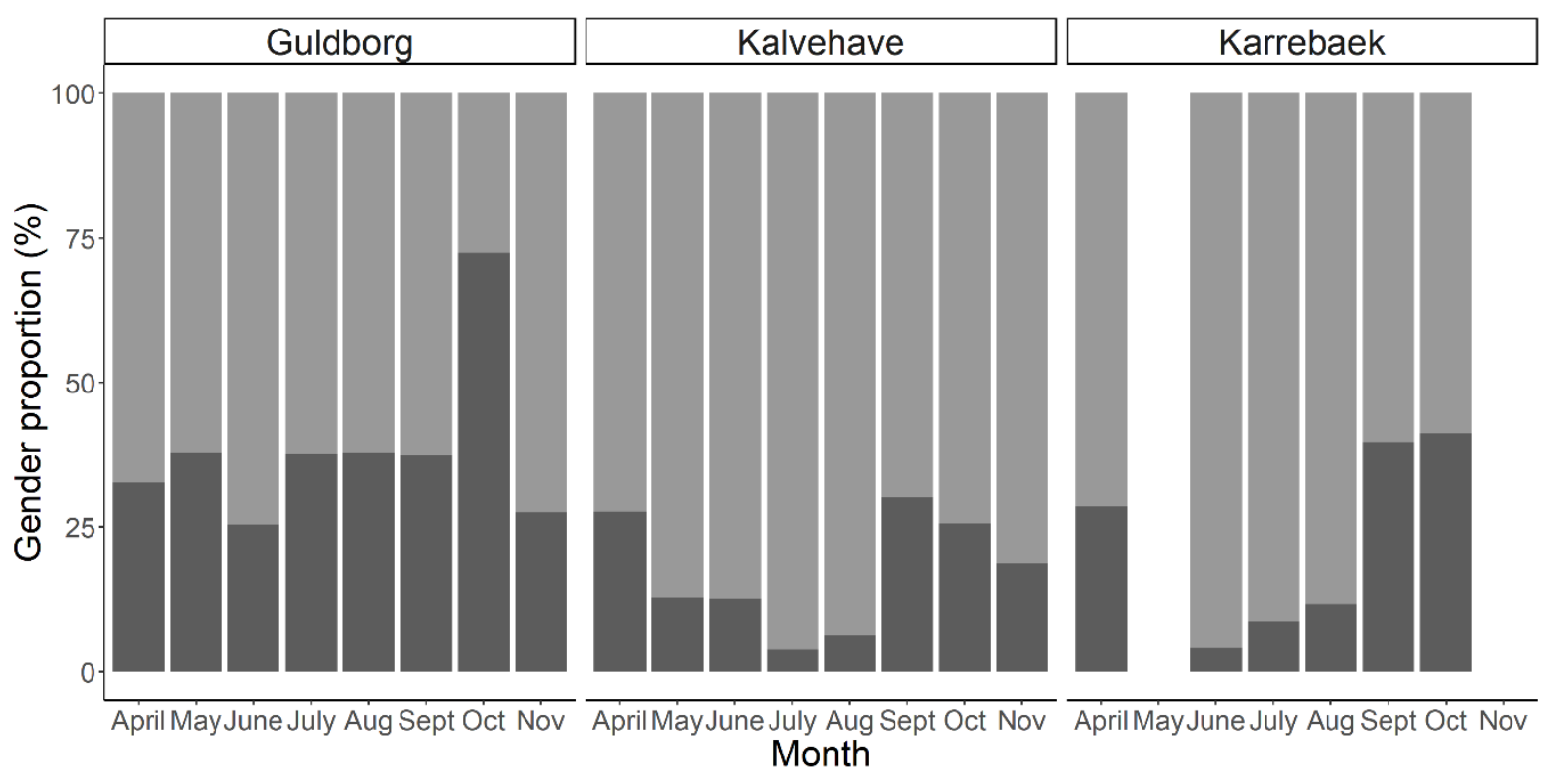

561 Fig 4

562

563 
A

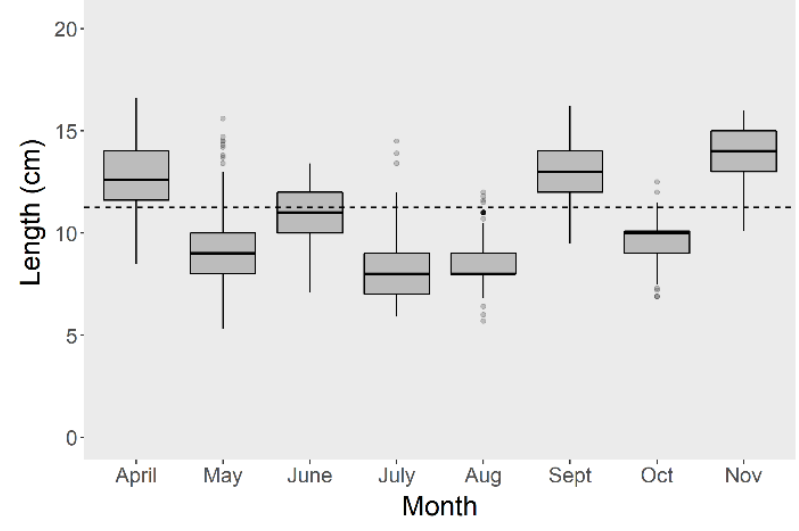

C

20 .

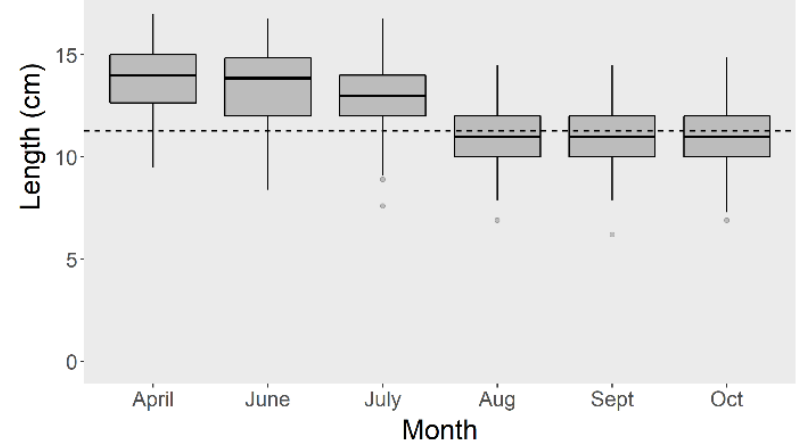

B

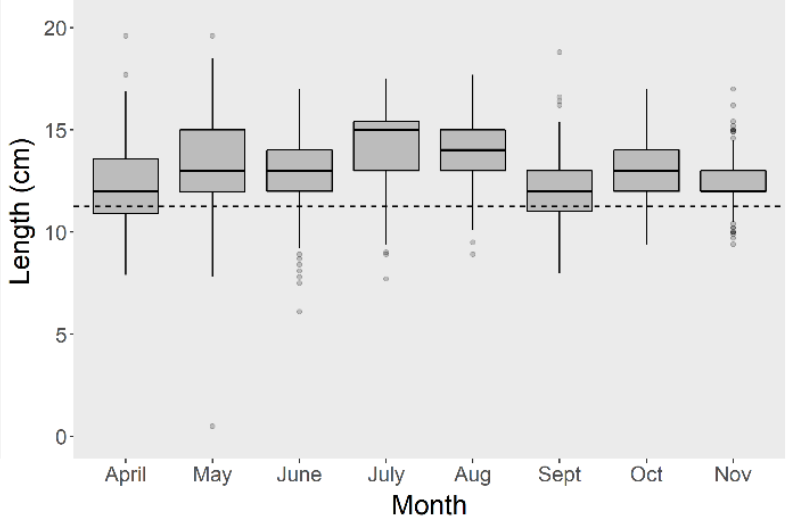

564

565 Fig 5

566

567 

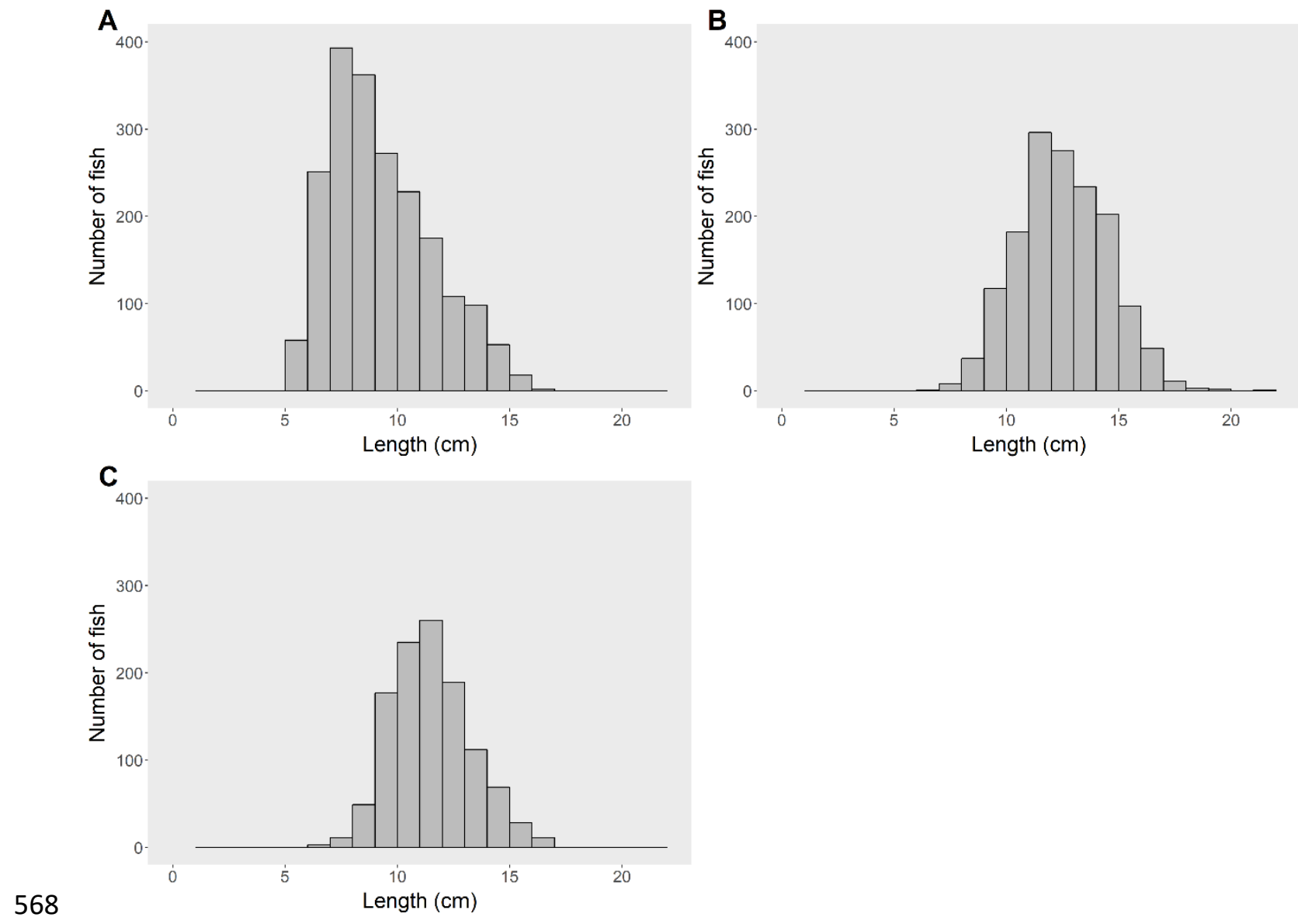

569 Fig 6

570

571 
A

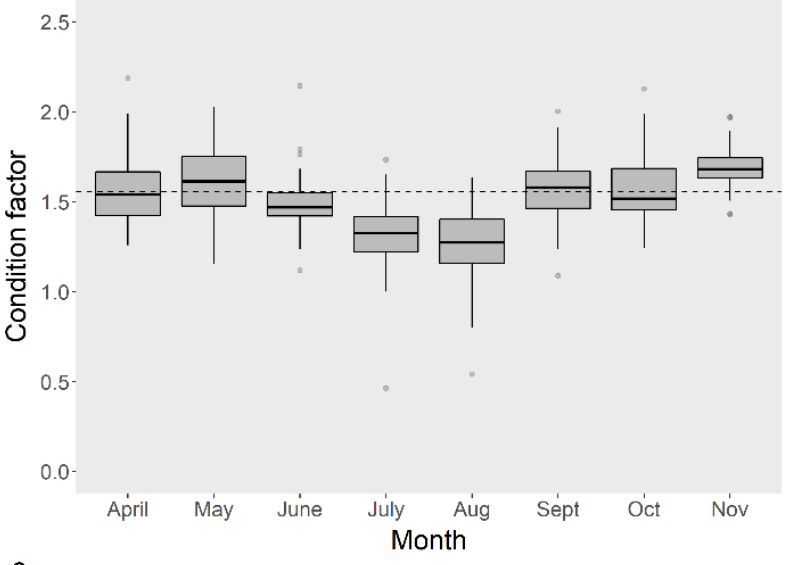

c

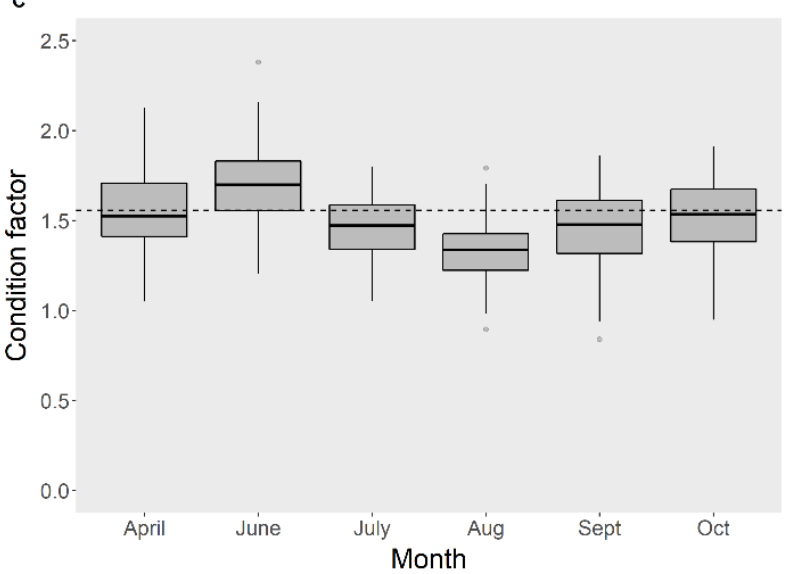

B

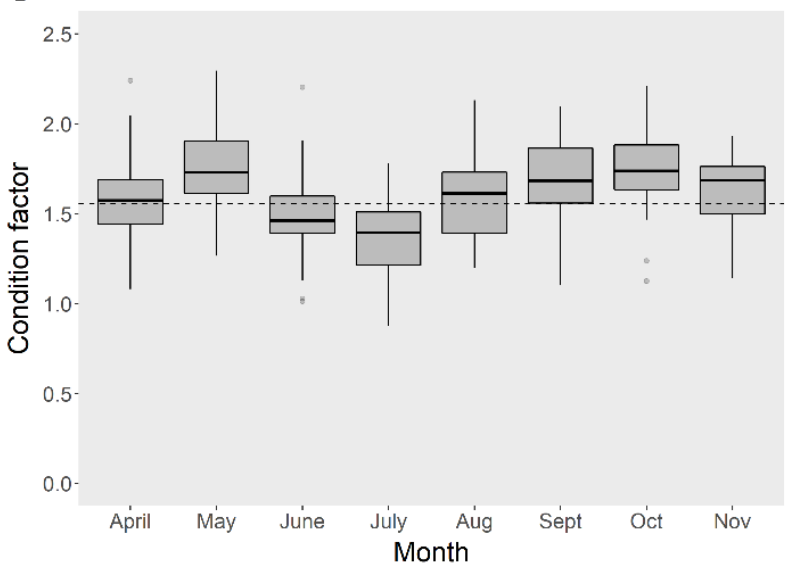

572

$573 \quad$ Fig 7

574

575

A

A
1.0

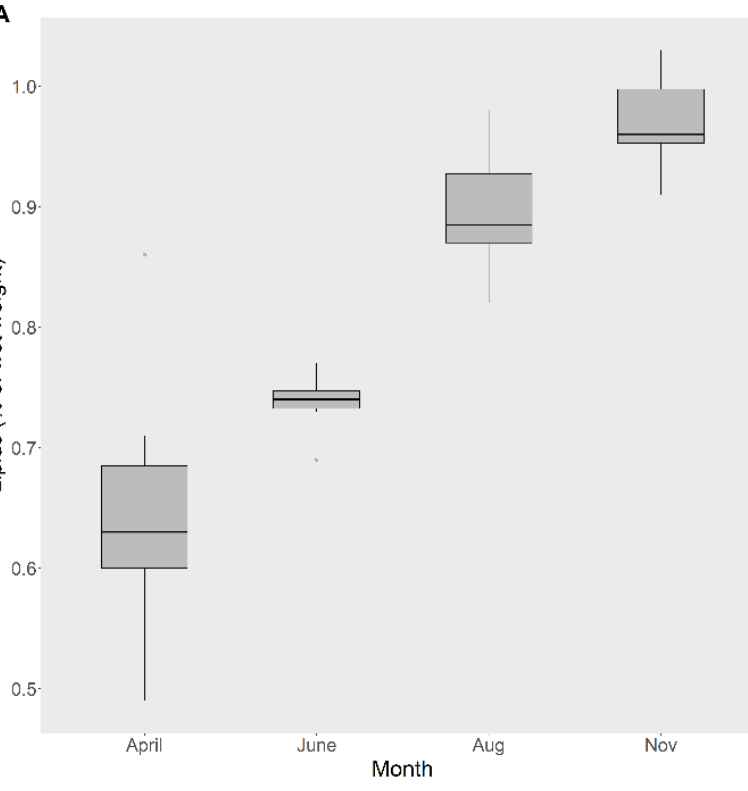

$\mathbf{B}_{20}$

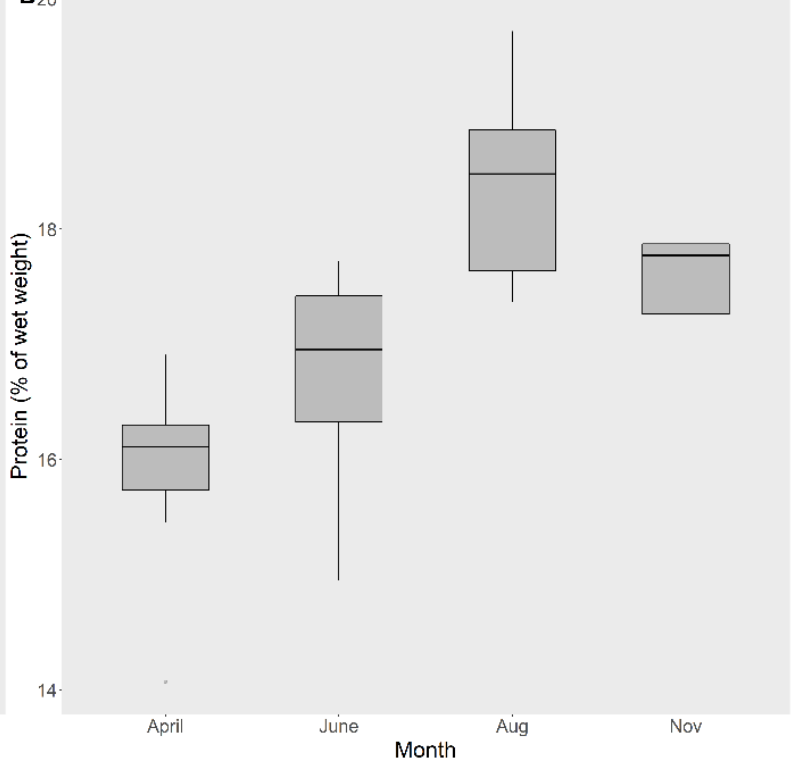


$577 \quad$ Fig 8

578

579

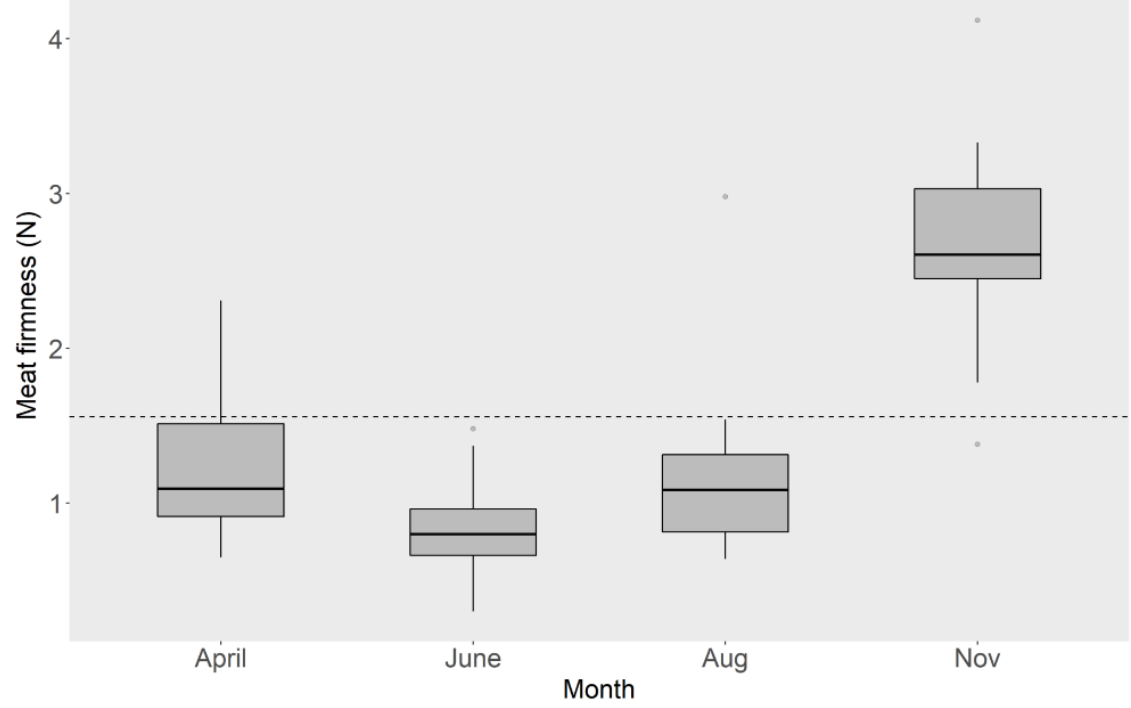

580

581 Fig 9

582

583 


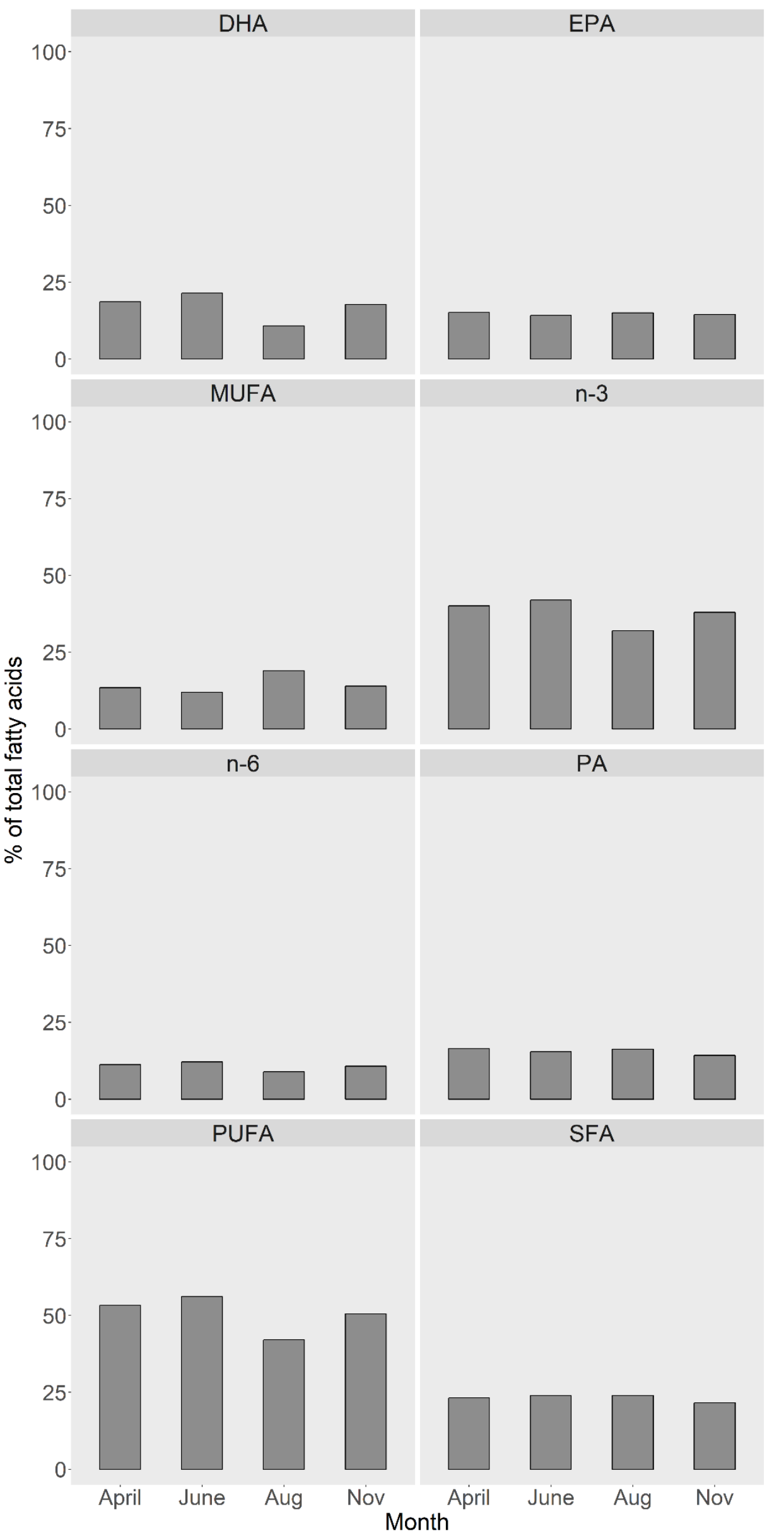


$585 \quad$ Fig 10

586

587

588

589 